\title{
Efficacy of Steinernema feltiae Filipjev, Native Entomopathogenic Nematode Kushidai Mamiya and their Bacterial Symbionts against Cnaphalocrocis medinalis Guenee
}

\author{
S. Karthikeyan*, T. Abdul Razak, A. Manivannan, S. Sekar and P.K. Muthu Kumar \\ ${ }^{1}$ Department of Agricultural Entomology, Agricultural College and Research Institute, \\ Killikulam, Tamil Nadu Agricultural University, Tamil Nadu, India - 628252 \\ *Corresponding author:
}

\section{A B S T R A C T}

\begin{tabular}{|l|}
\hline Ke y w or d s \\
Rice leaf folder, \\
Steinernema feltiae, \\
Steinernema \\
kushidai, \\
Xenorhabdus \\
\hline Article Info \\
\hline Accepted: \\
19 April 2017 \\
Available Online: \\
10 May 2017 \\
\hline \hline
\end{tabular}

The current study highlights the importance of entomopathogenic nematode (EPN), their bacterial symbionts and their combined efficacy along with Bacillus thuringiensis $(B t)$ in $C$. medinalis management. In the field experiment conducted at Thenthiruperai, Xenorhabdus bovienii $+B t$ and $X$. japonica combined with $B t$ found to be more effective with 80.54 per cent and 79.37 per cent reduction in larval population over untreated control respectively. X. japonica combined with $B t$ and $X$. bovienii combined with $B t$, were more effective with 69.38 per cent and 67.73 per cent reduction in leaf damage over control respectively. The native EPN S. kushidai showed 47.51 per cent reduction in leaf damage and it was 44.32 per cent in $S$. feltiae. In another experiment conducted at Anandanambikurichi revealed that $X$. bovienii+ $B t$ and the $X$. japonica $+B t$ proved superior efficacy with 72.59 and 69.33 per cent reduction in larval population over control respectively. S. kushidai KKM strain was better than $S$. feltiae as it could bring 55.77 per cent reduction in the larval population of $C$. medinalis. $X$. japonica $+B t$ and $X$. bovienii $+B t$ were found to be more effective with 71.23 per cent and 68.53 per cent reduction in leaf damage over untreated control respectively.

\section{Introduction}

Insect pests are important constrain in rice cultivation over the centuries; occurrence of pest outbreaks have increased with the change of pest status (Han et al., 2016; Ahmed et al., 2010). For instance, formerly considered as minor pest, leaffolder $C$. medinalis appears to be more destructive and widespread insect pest throughout the rice growing regions in South and South-East Asia (Dale, 1986; Rao et al., 2010; Park et al., 2014). In particular, heavy use of the insecticides and fertilizer seems to favour the $C$. medinalis population outbreaks. Cnaphalocrocis medinalis also induces rice sheath rot, difficulty in heading, and massive yield loss at the reproductive stage (Xiao, 1990). Although conventional chemical pesticides are used to protect rice against this pest; their use has caused concerns for food safety and environmental pollution (Kumar et al., 2011; Suganthi et al., 2011). Moreover, due to their frequent immigration and long incubation period, it is difficult to forecast the occurrence of rice leaffolder and effectively prevent its damage. Hence eco-friendly biocontrol agents like entomopathogenic nematodes (EPNs) and 
their bacterial symbionts shall be employed as potential biopesticides against this important foliage pest in rice.

Naturally occurring entomopathogenic nematodes and their symbiotic bacteria are important biotic factor in suppression of insect pest populations in soil and cryptic habitats. The virulent species of these nematodes are commercially produced as biological control agents all over the world (Divya and Sankar, 2009).

The infective juveniles (IJs) of EPNs are microscopic organisms having 0.5 to $1.5 \mathrm{~mm}$ long depending on species. EPNs enter through the insect's natural body openings, the mouth, anus or respiratory inlets (spiracles) and then penetrate into the blood cavity from the gut (Divya and Sankar, 2009); Heterorhabditis species can also penetrate through chinks in the insect's armour (the inter skeletal membranes) by scratching away with a special tooth (Bedding and Molyneux, 1982). Once in the insect's blood, infective juvenile releases highly specialized symbiotic bacteria such as Xenorhabdus spp. in Steinernema, and Photorhabdus spp. in Heterorhabditis (Muthulakshmi et al., 2011). These symbiotic bacteria multiply and rapidly kill the insect within a day or two. The bacteria then convert the insect into suitable food for the nematodes and produce a range of antibiotics (Uma et al., 2010) and antifeedants that preserve the dead insect from putrefaction while the nematodes feed and reproduce in it.

Earlier EPNs were mostly known as antagonists of soil pests, but in recent years many investigations have demonstrated that they can also be effectively used against foliar pests in various ecosystems including rice (Srinivas and Prasad, 1991; Arthurs et al., 2004). With this background, present investigation is carried out to explore the potential of EPNs and its bacterial symbionts against leaf folder.

\section{Materials and Methods}

\section{Mass culturing of $C$. medinalis}

In the screen house at the Department of Plant Protection, Agricultural College and Research Institute, Killikulam, the rice leaffolder $C$. medinalis was mass cultured on $\mathrm{TN}-1$ rice seedlings as per the standard protocol described by Heinrichs et al., (1985).

\section{EPN cultures}

\section{Host insect Corcyra cephalonica Staint}

In the bio-control laboratory at Agricultural College and Research Institute, Killikulam, the rice moth Corcyra cephalonica Staint was mass multiplied on half broken pearl millet grains by following the standard procedure given by Manjunath (1988). C. cephalonica larva was used as host insect for mass multiplication of EPNs.

\section{Mass culturing of EPNs}

The mother culture of $S$ feltiae in distilled water was obtained from Nematology Department, TNAU, and Coimbatore. The IJs were mass multiplied on grown up larvae of C. cephalonica in Petri dishes in laboratory condition. Ten grown up larvae were taken in $10 \mathrm{~cm}$ diameter Petri dish which was lined inside with Whatman No. 41 filter paper already inoculated with $S$. feltiae from the mother culture@10 IJs / larva. The dead larvae two days after inoculation were collected, washed with sterile water and kept at room temperature for further multiplication of the nematode. On fifth day the multiplied IJs were recovered by White's technique (White, 1927). Harvested IJs were stored in 0.1 per cent formalin in tissue culture flasks. 
The culture was aerated once in a week and re-culture were done once in 15 days in grown up C. cephalonica larva.

\section{Bacterial isolation}

Symbiotic bacteria were obtained from the haemolymph of $C$. cephalonica larvae infected with IJs of $S$. feltiae by following standard protocol given by Kaya and Stock (1997). The dead larvae of $C$. cephalonica after 24-48 hrs of inoculation were surfacesterilized in 70 per cent alcohol for $10 \mathrm{~min}$ and they were opened with sterile needles and scissors without damaging the gut and a drop of the oozing haemolymph was streaked with a needle onto nutrient agar plates (37 g nutrient agar; $25 \mathrm{mg}$ Bromothymol blue powder (Raymond); $4 \mathrm{ml}$ of filtrates of $1 \%$ 2,3,5-Triphenyltetrazolium Chloride (BDH); $1000 \mathrm{ml}$ distilled water). The agar plates after sealing with Parafilm were incubated at room temperature in the dark for $24 \mathrm{hrs}$. A single colony of bacterium was selected and it was streaked onto new plates of nutrient agar. Sub-culturing was continued until colonies of uniform size and morphology was obtained. The pathogenicity of the isolates was confirmed by inoculating (injecting) the bacterial cells into the body of $C$. cephalonica larvae and streaking the haemolymph of the infected larvae on NBTA plates. A single colony of the bacterium was selected and inoculated into $500 \mathrm{ml}$ of nutrient broth solution, containing $15 \mathrm{~g}$ nutrient broth and $500 \mathrm{ml}$ of distilled water in a flask stoppered with sterile cotton wool. The bacterial concentration of the broth suspensions were determined by a plate count method. The concentration of the bacterial cells in the present experiment was adjusted to $1 \times 10^{9}$ cells per $\mathrm{ml}$ and wetting agent Sandovit $0.5 \mathrm{ml}$ per litre was added as surfactant.

\section{Experimental design}

In the present study, rice varieties ADT 43, Madurai Ponni were used for field experiment. The present study was aimed to find out the influence of EPNs and their bacterial symbionts against $C$. medinalis larva and the damage inflicted to the leaves. The above rice variety was raised adopting the recommended package of agronomic practices. The experiment was conducted in a randomized block design with seven treatments replicated thrice with plot size of $5.0 \mathrm{~m} \times 4.0 \mathrm{~m}$. Totally two field trials were conducted at two nearby villages namely Thenthiruperai and Anandanambikurichi. Spraying was done at evening hours at 4.00 pm to $6.00 \mathrm{pm}$ with hand operated high volume knapsack sprayer.

\begin{tabular}{|l|l|l|}
\hline Field Trial & Place & Variety \\
\hline I & Thenthiruperai & ADT -43 \\
\hline II & Anandhanambikuruchi & Madurai Ponni \\
\hline
\end{tabular}

\begin{tabular}{|l|l|l|}
\hline S.No & Treatment & Dosage \\
\hline 1 & S. feltiae & $1 \times 10^{5} \mathrm{IJs} / \mathrm{ml}$ \\
\hline 2 & Native EPN strain & $1 \times 10^{5} \mathrm{IJs} / \mathrm{ml}$ \\
\hline 3 & Baterial symbionts of S. feltiae & $1 \times 10^{9}$ cells $/ \mathrm{ml}$ \\
\hline 4 & Baterial symbionts of Native EPN strain & $1 \times 10^{9}$ cells $/ \mathrm{ml}$ \\
\hline 5 & Baterial symbionts of $S$. feltiae $+B t$ & $1 \times 10^{9}$ cells $/ \mathrm{ml}+\mathrm{Bt} 1 \mathrm{~g} / \mathrm{lit}$. \\
\hline 6 & Baterial symbionts of Native EPN strain $+B t$ & $1 \times 10^{9}$ cells $/ \mathrm{ml}+\mathrm{Bt} 1 \mathrm{~g} / \mathrm{lit}$. \\
\hline 7 & Untreated control & - \\
\hline
\end{tabular}


Fresh damage of leaves after treatment was taken into count for calculating the per cent leaf damage; observations were recorded from randomly selected 5 hills in each plot. The total number of leaf folder larvae in each plot was counted by visual observation.

\section{Statistical analysis}

All the field and laboratory experiment data were analysed using two factor analysis AGRES statistical package was used for data analysis.

\section{Results and Discussion}

Field efficacy of entomopathogenic nematodes and their bacterial symbionts for the management of $C$. medinalis at Thenthiruperai (Field trial I)

First field trial was conducted at Thenthiruperai village with the variety ADT 43. The leaf folder damage occurred during flower initiation stage of rice and it was ranged from 9.60 to 13.15 per cent. The pretreatment data were well above ETL in most of the plots and they were statistically nonsignificant. Hence the treatments were imposed. Larval count and per cent leaf damage were considered as parameters to assess the efficacy of different treatments and the results are furnished below.

\section{Larval count}

Among the treatments, $X$. bovienii $+B t$ and $X$. japonica combined with $B t$ found to be most effective with 80.54 per cent and 79.37 per cent reduction in larval population over untreated control respectively. It was followed by 65.03 per cent reduction in $S$. kushidai KKM strain and 59.87 per cent reduction in $S$. feltiae sprayed plots. In the absence of $B t$ combination, the bacterial symbionts of $S$. feltiae and S. kushidai KKM strain were found to be inferior treatments with 17.50 per cent and 13.45 per cent reduction in the $C$. medinalis larval population over untreated control respectively (Table 1).

Over all mean values of different days after treatment showed that three, five and seven days after treatments were on par with each other and the larval population in those days was 13.66, 13.47 and 13.95 per plot respectively. The larval count at a day after treatment showed the highest level of 22.75 larvae per plot.

Interaction effect between treatment and days after treatments were also statistically highly significant. $X$. japonica combined with $B t$ on third day after spray was found to show more efficacy as this treatment recorded 93.18 per cent reduction in larval population over untreated control plot in the same period of observation. Next, $X$. bovienii combined with $B t$ on fifth day after treatment showed better response as the reduction over control in this treatment was 91.97 per cent. $X$. bovienii combined with $B t$ on third day and the $X$. japonica combined with $B t$ on fifth day after treatment were statistically on par and the larval population was three per plot against 29.33 and 29 larvae in control plots.

However in the absence of $B t$, among the two bacterial symbionts, $X$. bovienii exhibited better result as it could cause 24.14 per cent reduction in larval population over untreated control, while the $X$. japonica caused only 16.10 per cent reduction on fifth day after treatment. Among two nematode species, $S$. kushidai KKM strain caused 79.54 per cent reduction in larval population over untreated control, whereas it was 76.13 per cent reduction in $S$. feltiae sprayed plots and the difference between both the nematodes were statistically not significant. 


\section{Leaf damage}

The overall mean data on above experiment revealed that the $X$. japonica combined with $B t$ and $X$. bovienii combined with $B t$ were more effective with 69.38 per cent and 67.73 per cent reduction in leaf damage over untreated control respectively. It was followed by 47.51 per cent reduction in $S$. kushidai KKM strain and 44.32 per cent reduction in S. feltiae, both were statistically on par with each other. Xenorhabdus bovienii alone and $X$. japonica alone were found to be inferior with 29.77 per cent and 26.65 per cent reduction in leaf damage over untreated control respectively (Table 2).

Over all mean values of different days after treatments showed that seven days after treatment was the most effective with 61.63 per cent reduction in leaf damage. Three and five days after treatment were statistically on par with 46.88 per cent and 50.32 per cent reduction in leaf damage respectively. The leaf damage at a day after treatment showed poor result with 31.91 per cent reduction in leaf damage over untreated control.

The interaction effect between treatments and days after treatment were statistically highly significant. X. bovienii combined with $B t$ on seventh day after treatment was found to be highly efficient as this recorded 83.34 per cent reduction in leaf damage over untreated control plot in the same period of observation. Next, the $X$. japonica combined with $B t$ showed better response by showing 67.74 and 80.30 per cent reduction over control on fifth and seventh day after treatment respectively. However both the bacterial symbionts without $B t$ showed poor result and among them $X$. bovienii was better with $31.24-33.92$ per cent reduction over control during fifth to seventh day after spray. Among the two entomopathogenic nematodes, the S. kushidai was the most effective one with 70.01 per cent reduction in leaf damage over control, while S. feltiae recorded 65.22 per cent reduction over control on seven days after treatment.

Field efficacy of entomopathogenic nematodes and their bacterial symbionts for the management of $C$. medinalis at Anandanambikurichi (Field trial II)

Second field trial was conducted at Anandanambikurichi village with the variety Madurai Ponni. The leaffolder damage occurred during vegetative growth stage and it ranged from 10.59 to 12.92 per cent. As the pre treatment data were well above ETL and they were statistically non- significant, spraying of different treatment suspensions was carried out. Larval count and per cent leaf damage were considered as parameters to assess the efficacy of different treatments and the results are furnished below (Table 3,4).

\section{Larval count}

The mean data showed that $X$. bovienii $+B t$ and the $X$. japonica $+B t$ proved superior efficacy with 72.59 and 69.33 per cent reduction in larval population over control respectively. These bacteria in the absence of $B t$ was found to be less effective against $C$. medinalis larva and among them $X$. bovienii was the least one with 13.42 per cent reduction while the $X$. japonica showed 23.45 per cent reduction over control. Although there is no significant difference among the two EPNs, the S. kushidai KKM strain was numerically better as it could bring 55.77 per cent reduction in the larval population.

Over all mean values of different days after treatments showed that three, five and seven days after treatment was effective and they were on par with each other and the population on those days was $21.19,20.86$ and 18.76 larvae per plot respectively. The 
larval population on the first day after spray was found higher (31.24 larvae per plot).

The interaction effect between treatments and days after treatment revealed that $X$. bovienii along with $B t$ drastically reduced the larval population of $C$. medinalis by $79.83,79.00$ and 76.52 per cent over control plot respectively and they were on par statistically on third, fifth and seventh day after spray. Next, $X$. japonica along with $B t$ at three, five, and seven days after treatment were found be effective with larval population of 9.00, 10.33 and 11.0 larvae per plot respectively. Among the two nematode species, S. kushidai on seventh day after treatment was the most effective nematode with 67.83 per cent reduction over untreated control and it was 64.36 per cent in $S$. feltiae on the same period of observation.

\section{Leaf damage}

Effect of entomopathogenic nematodes (EPN) and their bacterial symbionts in managing the leaf damage by $C$. medinalis was realized in all the treatments and significant differences between the days after spray was also evident. Interaction effects between treatment and days after spray were found to be nonsignificant.

Overall mean values of different treatments in managing the leaf damage clearly showed that the $X$. japonica along with $B t$ and $X$. bovienii along with $B t$ were the most effective with 71.23 per cent and 68.53 per cent reduction in leaf damage over untreated control respectively and they were found to be equally effective statistically. It was followed by $S$. kushidai KKM strain with 37.72 per cent reduction and $S$. feltiae with 40.02 per cent reduction over untreated control and they were found to be non significant. The efficacy of sole application of either the $X$. japonica or $X$. bovienii was inferior to all other treatments with $19.39-22.28$ per cent reduction in the leaf damage over control.

Similarly over all mean values of all the treatments at different days after spray showed that, seven days after treatment was effective with 60.15 per cent reduction of leaf damage. Three and five days after spray were statistically on par with $35.90-46.23$ per cent reduction in leaf damage. The leaf damage on a day after spray was poor with 31.67 per cent reduction in leaf damage over untreated control.

Among various treatments, the two bacterial symbionts in combination with $B t$ were the most effective in reducing both the larval population and per cent leaf damage in both field trials. However, they were found to be inferior in the absence of $B t$. The reason for enhancement in virulence of the bacterial symbionts in the presence of $B t$ has already been discussed in the laboratory studies showing similar results.

A study of Jung and Kim (2006) says that the bacterial mixture of $B t$ and symbiotic bacteria was highly synergistic against fifth instar larvae Spodoptera exigua and they reported that mixture of Xenorhabdus sp. and $B t$ induced higher mortality when compared with sole application. This study supports our results that both the symbiotic bacteria applied individually in fields exhibited poor result. Thus mixing of $B t$ with symbiotic bacteria synergistically enhanced the efficacy against rice leaf folder. Next to the bacterial symbiont, the two EPNs tested were found to be better as they could suppress the leaf folder larvae and leaf damage per cent in the field conditions. The microclimate of rice culture with high humidity and moderate temperature is conductive for the survival, movement, tracking and invasion of the host by EPN and their establishment as a bio-control agent (Sankar et al., 2009). 
Table.1 Efficacy of entomopathogenic nematodes and their bacterial symbionts against $C$. medinalis larva in Field trial I (village: Thenthiruperai)

\begin{tabular}{|c|c|c|c|c|c|c|c|}
\hline \multirow[b]{2}{*}{ TREATMENT } & \multirow[b]{2}{*}{ Dose } & \multicolumn{4}{|c|}{ Larval population } & \multirow[b]{2}{*}{$\begin{array}{c}\text { Mean } \\
(\mathbf{T})\end{array}$} & \multirow{2}{*}{$\begin{array}{c}\text { Percent } \\
\text { reduction } \\
\text { over } \\
\text { control } \\
(\%)\end{array}$} \\
\hline & & I DAT & III DAT & V DAT & $\begin{array}{l}\text { VII } \\
\text { DAT }\end{array}$ & & \\
\hline S.feltiae & $\begin{array}{l}1 \times 10^{5} \\
\mathrm{IJs} / \mathrm{ml}\end{array}$ & $\begin{array}{c}24.00 \\
(4.89)^{\mathrm{GH}}\end{array}$ & $\begin{array}{c}7.00 \\
(2.58)^{\mathrm{DE}}\end{array}$ & $\begin{array}{c}7.33 \\
(2.82)^{\mathrm{DE}}\end{array}$ & $\begin{array}{c}8.33 \\
(2.89)^{\mathrm{E}}\end{array}$ & $\begin{array}{c}11.67 \\
(3.30) c\end{array}$ & 59.87 \\
\hline $\begin{array}{l}\text { S. kushidai } \\
\text { KKM strain }\end{array}$ & $\begin{array}{l}1 \times 10^{5} \\
\mathrm{IJs} / \mathrm{ml}\end{array}$ & $\begin{array}{c}21.33 \\
(4.62)^{\mathrm{G}}\end{array}$ & $\begin{array}{c}6.00 \\
(2.44)^{\mathrm{D}}\end{array}$ & $\begin{array}{c}6.33 \\
(2.51)^{\mathrm{DE}}\end{array}$ & $\begin{array}{c}7.00 \\
(2.64)^{\mathrm{DE}}\end{array}$ & $\begin{array}{c}10.17 \\
(3.05) b\end{array}$ & 65.03 \\
\hline$X$. bovienii & $\begin{array}{c}1 \times 10^{9} \\
\text { cells } / \mathrm{ml}\end{array}$ & $\begin{array}{c}27.33 \\
(5.23)^{\mathrm{HIJK}}\end{array}$ & $\begin{array}{c}23.33 \\
(4.83)^{\mathrm{G}}\end{array}$ & $\begin{array}{l}22.00 \\
(4.68)^{\mathrm{G}}\end{array}$ & $\begin{array}{l}23.33 \\
(4.81)^{\mathrm{G}}\end{array}$ & $\begin{array}{c}23.99 \\
(4.89) d\end{array}$ & 17.50 \\
\hline$X$. japonica & $\begin{array}{c}1 \times 10^{9} \\
\text { cells } / \mathrm{ml}\end{array}$ & $\begin{array}{c}28.00 \\
(5.29)^{\mathrm{IJK}}\end{array}$ & $\begin{array}{c}25.00 \\
(4.99)^{\text {GHIJ }}\end{array}$ & $\begin{array}{c}24.33 \\
(4.93)^{\mathrm{GHI}}\end{array}$ & $\begin{array}{c}23.33 \\
(4.82)^{\mathrm{G}}\end{array}$ & $\begin{array}{c}25.17 \\
(5.01) d\end{array}$ & 13.45 \\
\hline$X$. bovienii $+B t$ & $\begin{array}{c}1 \times 10^{9} \\
\text { cells } / \mathrm{ml}+B t \\
1 \mathrm{~g} / \mathrm{lit} .\end{array}$ & $\begin{array}{l}14.00 \\
(3.74)^{\mathrm{F}}\end{array}$ & $\begin{array}{c}3.00 \\
(1.72)^{\mathrm{ABC}}\end{array}$ & $\begin{array}{c}2.33 \\
(1.49)^{\mathrm{AB}}\end{array}$ & $\begin{array}{c}3.33 \\
(1.80)^{\mathrm{BC}}\end{array}$ & $\begin{array}{c}5.66 \\
(2.19) \mathbf{a} \\
\end{array}$ & 80.54 \\
\hline$X$. japonica $+B t$ & $\begin{array}{c}1 \times 10^{9} \\
\text { cells } / \mathrm{ml}+B t \\
1 \mathrm{~g} / \mathrm{lit} .\end{array}$ & $\begin{array}{c}15.00 \\
(3.87)^{\mathrm{F}}\end{array}$ & $\begin{array}{c}2.00 \\
(1.38)^{\mathrm{A}}\end{array}$ & $\begin{array}{c}3.00 \\
(1.72)^{\mathrm{ABC}}\end{array}$ & $\begin{array}{c}4.00 \\
(1.99)^{\mathrm{C}}\end{array}$ & $\begin{array}{c}6.00 \\
(2.23) \mathbf{a}\end{array}$ & 79.37 \\
\hline $\begin{array}{l}\text { Untreated } \\
\text { control }\end{array}$ & - & $\begin{array}{c}29.66 \\
(5.44)^{\mathrm{K}}\end{array}$ & $\begin{array}{c}29.33 \\
(5.42)^{\mathrm{K}}\end{array}$ & $\begin{array}{c}29.00 \\
(5.38)^{\mathrm{JK}}\end{array}$ & $\begin{array}{c}28.33 \\
(5.32)^{\mathrm{IJK}}\end{array}$ & $\begin{array}{c}29.08 \\
(5.39) \mathrm{e}\end{array}$ & - \\
\hline \multicolumn{2}{|c|}{ Mean(DAT) } & $\begin{array}{c}22.75 \\
(4.73) b\end{array}$ & $\begin{array}{c}13.66 \\
(3.34) a \\
\end{array}$ & $\begin{array}{c}13.47 \\
(3.36) \mathbf{a}\end{array}$ & $\begin{array}{c}13.95 \\
(3.47) \mathbf{a}\end{array}$ & $\begin{array}{l}15.96 \\
(3.72) \\
\end{array}$ & - \\
\hline
\end{tabular}

Figures in parentheses are square root transformed values.

In a column / row, means followed by a common letter are not significantly different at $1 \%$ level (LSD).

Significance

$\mathrm{T} \quad \mathrm{DAT}$

$\mathrm{CD}(\mathrm{p}=0.05)$

0.01

0.01

$\mathrm{T} \times \mathrm{DAT}$

0.20

0.15

0.01

T- Treatment

DAT- Days after treatment 
Table.2 Effect of entomopathogenic nematodes and their bacterial symbionts against leaffolder damage in Field trial - I (Village: Thenthiruperai)

\begin{tabular}{|c|c|c|c|c|c|c|c|}
\hline \multirow{2}{*}{ TREATMENT } & \multirow{2}{*}{ Dose } & \multirow{2}{*}{$\begin{array}{c}\text { Initial } \\
\text { damage } \\
(\%)\end{array}$} & \multicolumn{4}{|c|}{ Leaf damage ( $\%$ reduction over control)* } & \multirow{2}{*}{$\operatorname{Mean}(\mathbf{T})$} \\
\hline & & & I DAT & III DAT & V DAT & VII DAT & \\
\hline S. feltiae & $\begin{array}{l}1 \times 10^{5} \\
\mathrm{IJ} / \mathrm{ml}\end{array}$ & 12.12 & $\begin{array}{c}15.29 \\
(21.29) \mathrm{IJ}\end{array}$ & $\begin{array}{c}46.60 \\
(43.05)^{\mathrm{EFG}}\end{array}$ & $\begin{array}{c}50.17 \\
(45.09)^{\mathrm{CDEF}}\end{array}$ & $\begin{array}{c}65.22 \\
(54.04)^{\mathrm{BCDE}}\end{array}$ & $\begin{array}{c}44.32 \\
(40.87) b\end{array}$ \\
\hline $\begin{array}{l}\text { S. kushidai } \\
\text { KKM strain }\end{array}$ & $\begin{array}{l}1 \times 10^{5} \\
\mathrm{IJs} / \mathrm{ml}\end{array}$ & 13.15 & $\begin{array}{c}13.74 \\
(19.86) \mathrm{J}\end{array}$ & $\begin{array}{c}48.92 \\
(44.38)^{\mathrm{DEF}}\end{array}$ & $\begin{array}{c}57.38 \\
(49.29)^{\mathrm{CDE}}\end{array}$ & $\begin{array}{c}70.01 \\
(56.85)^{\mathrm{ABC}}\end{array}$ & $\begin{array}{c}47.51 \\
(42.59) b\end{array}$ \\
\hline$X$. bovienii & $\begin{array}{c}1 \times 10^{9} \\
\text { cells } / \mathrm{ml}\end{array}$ & 11.13 & $\begin{array}{c}21.69 \\
(27.25)^{\mathrm{HIJ}}\end{array}$ & $\begin{array}{c}31.24 \\
(33.82)^{\mathrm{FGH}}\end{array}$ & $\begin{array}{c}32.22 \\
(34.51)^{\mathrm{FGH}}\end{array}$ & $\begin{array}{c}33.92 \\
(35.30)^{\mathrm{FGH}}\end{array}$ & $\begin{array}{c}29.77 \\
(32.72) c\end{array}$ \\
\hline X. japonica & $\begin{array}{c}1 \times 10^{9} \\
\text { cells } / \mathrm{ml}\end{array}$ & 12.45 & $\begin{array}{c}17.26 \\
(21.49)^{\mathrm{IJ}}\end{array}$ & $\begin{array}{c}28.18 \\
(31.69)^{\mathrm{GHI}}\end{array}$ & $\begin{array}{c}27.16 \\
(31.07)^{\mathrm{HIJ}}\end{array}$ & $\begin{array}{c}34.01 \\
(35.27)^{\mathrm{FGH}}\end{array}$ & $\begin{array}{c}26.65 \\
(29.88) c\end{array}$ \\
\hline$X$. bovienii $+B t$ & $\begin{array}{c}1 \times 10^{9} \\
\text { cells } / \mathrm{ml}+B t \\
1 \mathrm{~g} / \mathrm{lit} .\end{array}$ & 9.60 & $\begin{array}{c}59.39 \\
(50.64)^{\mathrm{CDE}}\end{array}$ & $\begin{array}{c}60.92 \\
(51.40)^{\mathrm{CDE}}\end{array}$ & $\begin{array}{c}67.26 \\
\left(\begin{array}{c}55.64) \\
\text { ABCD }\end{array}\right.\end{array}$ & $\begin{array}{c}83.34 \\
(66.02)^{\mathrm{A}}\end{array}$ & $\begin{array}{c}67.73 \\
(\mathbf{5 5 . 9 3 ) a}\end{array}$ \\
\hline$X$. japonica $+B t$ & $\begin{array}{c}1 \times 10^{9} \\
\text { cells } / \mathrm{ml}+B t \\
1 \mathrm{~g} / \mathrm{lit}\end{array}$ & 11.77 & $\begin{array}{c}64.07 \\
(53.66)^{\mathrm{BCDE}}\end{array}$ & $\begin{array}{c}65.43 \\
(54.14)^{\mathrm{BCDE}}\end{array}$ & $\begin{array}{c}67.74 \\
(56.31)^{\mathrm{ABC}}\end{array}$ & $\begin{array}{c}80.30 \\
(63.81)^{\mathrm{AB}}\end{array}$ & $\begin{array}{c}69.38 \\
(56.98) a\end{array}$ \\
\hline $\begin{array}{l}\text { Untreated } \\
\text { control }\end{array}$ & - & 11.46 & - & - & - & - & - \\
\hline \multicolumn{3}{|c|}{ Mean(DAT) } & $\begin{array}{c}31.91 \\
(32.37) \mathrm{c}\end{array}$ & $\begin{array}{c}46.88 \\
(43.08) b\end{array}$ & $\begin{array}{c}50.32 \\
(45.32) b\end{array}$ & $\begin{array}{c}61.63 \\
(51.88) a\end{array}$ & $\begin{array}{c}47.56 \\
(43.16)\end{array}$ \\
\hline
\end{tabular}

Figures in parentheses are arcsine transformed values.

In a column / row, means followed by a common letter are not significantly different at $1 \%$ level (LSD).

* In a column / row, means followed by a common letter are not significantly different at 5\% level (LSD).

Significance

$\mathrm{CD}(\mathrm{p}=0.05)$

T- Treatment

DAT- Days after treatment

$\begin{array}{ccc}\mathrm{T} & \mathrm{DAT} & \mathrm{T} \times \mathrm{DAT} \\ 0.01 & 0.01 & 0.05 \\ 5.90 & 4.82 & 11.80\end{array}$

$\begin{array}{lll}5.90 & 4.82 & 11.80\end{array}$ 
Table.3 Efficacy of entomopathogenic nematodes and their bacterial symbionts against C. medinalis larva in Field trial II (village: Anandanambikurichi)

\begin{tabular}{|c|c|c|c|c|c|c|c|}
\hline \multirow[b]{2}{*}{ TREATMENT } & \multirow[b]{2}{*}{ Dose } & \multicolumn{4}{|c|}{ Larval population } & \multirow[b]{2}{*}{$\operatorname{Mean}(T)$} & \multirow{2}{*}{$\begin{array}{c}\text { Per cent } \\
\text { reduction } \\
\text { over } \\
\text { control }(\%)\end{array}$} \\
\hline & & I DAT & III DAT & V DAT & VII DAT & & \\
\hline S.feltiae & $\begin{array}{l}1 \times 10^{5} \\
\mathrm{IJ} / \mathrm{ml}\end{array}$ & $\begin{array}{c}35.33 \\
(5.92)^{\mathrm{HIJ}}\end{array}$ & $\begin{array}{c}12.00 \\
(3.45)^{\mathrm{BCD}}\end{array}$ & $\begin{array}{c}13.33 \\
(3.65)^{\mathrm{D}}\end{array}$ & $\begin{array}{c}13.66 \\
(3.69)^{\mathrm{D}}\end{array}$ & $\begin{array}{c}18.58 \\
(4.18) b\end{array}$ & 53.49 \\
\hline $\begin{array}{l}\text { S. kushidai } \\
\text { KKM strain }\end{array}$ & $\begin{array}{l}1 \times 10^{5} \\
\mathrm{IJ} / \mathrm{ml}\end{array}$ & $\begin{array}{c}33.00 \\
(5.74)^{\mathrm{FGHI}}\end{array}$ & $\begin{array}{c}12.33 \\
(3.50)^{\mathrm{CD}}\end{array}$ & $\begin{array}{c}13.00 \\
(3.56)^{\mathrm{D}}\end{array}$ & $\begin{array}{c}12.33 \\
(3.48)^{\mathrm{BCD}}\end{array}$ & $\begin{array}{c}17.67 \\
(4.07) b\end{array}$ & 55.77 \\
\hline$X$. bovienii & $\begin{array}{c}1 \times 10^{9} \\
\text { cells } / \mathrm{ml}\end{array}$ & $\begin{array}{c}37.67 \\
(6.13)^{\mathrm{HIJK}}\end{array}$ & $\begin{array}{c}35.67 \\
(5.97)^{\mathrm{HIJK}}\end{array}$ & $\begin{array}{c}32.33 \\
(5.68)^{\text {FGHI }}\end{array}$ & $\begin{array}{c}32.67 \\
(5.71)^{\mathrm{FGHI}}\end{array}$ & $\begin{array}{c}34.59 \\
(5.87) d\end{array}$ & 13.42 \\
\hline X. japonica & $\begin{array}{c}1 \times 10^{9} \\
\text { cells } / \mathrm{ml}\end{array}$ & $\begin{array}{c}34.00 \\
(5.83)^{\mathrm{GHIJ}}\end{array}$ & $\begin{array}{c}31.33 \\
(5.60)^{\mathrm{FGH}}\end{array}$ & $\begin{array}{c}29.00 \\
(5.38)^{\mathrm{FG}}\end{array}$ & $\begin{array}{l}28.00 \\
(5.29)^{\mathrm{F}}\end{array}$ & \begin{tabular}{|c|}
30.58 \\
$(5.53) c$
\end{tabular} & 23.45 \\
\hline$X$. bovienii $+B t$ & $\begin{array}{c}1 \times 10^{9} \\
\text { cells } / \mathrm{ml}+B t \\
1 \mathrm{~g} / \mathrm{lit}\end{array}$ & $\begin{array}{c}18.00 \\
(4.24)^{\mathrm{E}}\end{array}$ & $\begin{array}{c}8.00 \\
(2.87)^{\mathrm{A}}\end{array}$ & $\begin{array}{c}8.33 \\
(2.88)^{\mathrm{A}}\end{array}$ & $\begin{array}{c}9.00 \\
(2.95)^{\mathrm{AB}}\end{array}$ & $\begin{array}{c}10.95 \\
(3.23) a\end{array}$ & 72.59 \\
\hline$X$. japonica $+B t$ & $\begin{array}{c}1 \times 10^{9} \\
\text { cells } / \mathrm{ml}+B t \\
1 \mathrm{~g} / \mathrm{lit} .\end{array}$ & $\begin{array}{c}18.67 \\
(4.31)^{\mathrm{E}}\end{array}$ & $\begin{array}{c}9.00 \\
(2.98)^{\mathrm{ABC}}\end{array}$ & $\begin{array}{c}10.33 \\
(3.21)^{\mathrm{ABCD}}\end{array}$ & $\begin{array}{c}11.00 \\
(3.31)^{\mathrm{ABCD}}\end{array}$ & $\begin{array}{c}12.25 \\
(3.45) a\end{array}$ & 69.33 \\
\hline $\begin{array}{l}\text { Untreated } \\
\text { control }\end{array}$ & - & $\begin{array}{c}42.00 \\
(6.48)^{\mathrm{K}}\end{array}$ & $\begin{array}{c}39.67 \\
(6.30)^{\mathrm{JK}}\end{array}$ & $\begin{array}{c}39.67 \\
(6.30)^{\mathrm{JK}}\end{array}$ & $\begin{array}{c}38.33 \\
(6.19)^{\mathrm{IJK}}\end{array}$ & $\begin{array}{c}39.95 \\
(6.32) \mathrm{e}\end{array}$ & - \\
\hline Mean & & $\begin{array}{c}31.24 \\
(5.52) b\end{array}$ & $\begin{array}{c}21.19 \\
(4.38) \mathrm{a}\end{array}$ & $\begin{array}{c}20.86 \\
(4.38) a\end{array}$ & $\begin{array}{c}18.76 \\
(4.37) a\end{array}$ & $\begin{array}{l}23.51 \\
(4.66)\end{array}$ & - \\
\hline
\end{tabular}

Figures in parentheses are square root transformed values.

In a column / row, means followed by a common letter are not significantly different at $1 \%$ level (LSD).

$\begin{array}{lccc}\text { Significance } & \text { T } & \text { DAT } & \text { T } \times \text { DAT } \\ \text { CD }(p=0.05) & 0.01 & 0.01 & 0.01 \\ & 0.27 & 0.20 & 0.53\end{array}$

T- Treatment ; DAT- Days after treatment 
Table.4 Effect of entomopathogenic nematodes and their bacterial symbionts against leaffolder damage in Field trial - II (Village: Anandanambikurichi)

\begin{tabular}{|c|c|c|c|c|c|c|c|}
\hline \multirow{2}{*}{ TREATMENT } & \multirow{2}{*}{ Dose } & \multirow{2}{*}{$\begin{array}{c}\text { Initial } \\
\text { damage } \\
(\%)\end{array}$} & \multicolumn{4}{|c|}{$\begin{array}{c}\text { Leaf damage ( } \% \text { reduction over } \\
\text { control) }\end{array}$} & \multirow{2}{*}{ Mean(T) } \\
\hline & & & I DAT & $\begin{array}{c}\text { III } \\
\text { DAT }\end{array}$ & $\begin{array}{l}\text { V } \\
\text { DAT }\end{array}$ & $\begin{array}{c}\text { VII } \\
\text { DAT }\end{array}$ & \\
\hline S.feltiae & $1 \times 10^{5} \mathrm{IJ} / \mathrm{ml}$ & 12.16 & $\begin{array}{l}17.13 \\
(23.90)\end{array}$ & $\begin{array}{l}20.55 \\
(23.49)\end{array}$ & $\begin{array}{c}56.09 \\
(48.69)\end{array}$ & $\begin{array}{r}66.29 \\
(54.62) \\
\end{array}$ & $\begin{array}{c}40.02 \\
(37.68) b\end{array}$ \\
\hline $\begin{array}{l}\text { S. kushidai } \\
\text { KKM strain }\end{array}$ & $1 \times 10^{5} \mathrm{IJs} / \mathrm{ml}$ & 10.59 & $\begin{array}{c}23.45 \\
(28.47)\end{array}$ & $\begin{array}{c}24.48 \\
(29.61)\end{array}$ & $\begin{array}{c}38.43 \\
(37.94)\end{array}$ & $\begin{array}{c}64.54 \\
(53.75)\end{array}$ & $\begin{array}{c}37.72 \\
(37.44) b\end{array}$ \\
\hline$X$. bovienii & $1 \times 10^{9}$ cells $/ \mathrm{ml}$ & 12.41 & $\begin{array}{c}8.84 \\
(15.87) \\
\end{array}$ & $\begin{array}{c}19.21 \\
(25.24) \\
\end{array}$ & $\begin{array}{c}22.37 \\
(27.36) \\
\end{array}$ & $\begin{array}{c}27.11 \\
(26.63) \\
\end{array}$ & $\begin{array}{c}19.39 \\
(23.77) c\end{array}$ \\
\hline X. japonica & $1 \times 10^{9}$ cells $/ \mathrm{ml}$ & 12.88 & $\begin{array}{c}15.41 \\
(22.48)\end{array}$ & $\begin{array}{c}17.74 \\
(23.97)\end{array}$ & $\begin{array}{c}22.28 \\
(22.77)\end{array}$ & $\begin{array}{c}40.85 \\
(36.79)\end{array}$ & $\begin{array}{c}22.28 \\
(26.51) c\end{array}$ \\
\hline$X$. bovienii $+B t$ & $\begin{array}{c}1 \times 10^{9} \text { cells } / \mathrm{ml}+B t \\
1 \mathrm{~g} / \mathrm{lit} .\end{array}$ & 12.92 & $\begin{array}{c}60.76 \\
(51.28)\end{array}$ & $\begin{array}{c}65.77 \\
(54.28)\end{array}$ & $\begin{array}{c}66.59 \\
(55.13)\end{array}$ & $\begin{array}{c}80.99 \\
(64.36)\end{array}$ & $\begin{array}{c}68.53 \\
(56.26) a\end{array}$ \\
\hline$X$. japonica $+B t$ & $\begin{array}{l}1 \times 10^{9} \text { cells } / \mathrm{ml}+B t \\
1 \mathrm{~g} / \mathrm{lit} .\end{array}$ & 12.77 & $\begin{array}{c}64.44 \\
(53.43)\end{array}$ & $\begin{array}{c}67.62 \\
(55.52)\end{array}$ & $\begin{array}{c}71.60 \\
(55.08)\end{array}$ & $\begin{array}{r}81.19 \\
(64.45) \\
\end{array}$ & $\begin{array}{c}71.23 \\
(57.87) a\end{array}$ \\
\hline Untreated control & - & 11.29 & - & - & - & - & - \\
\hline \multicolumn{3}{|c|}{ Mean(DAT) } & $\begin{array}{c}31.67 \\
(32.57) \\
c \\
\end{array}$ & $\begin{array}{c}35.90 \\
(35.35) \\
\text { b }\end{array}$ & $\begin{array}{c}46.23 \\
(41.16) \\
b\end{array}$ & $\begin{array}{c}60.15 \\
(50.1) \\
a \\
\end{array}$ & $\begin{array}{c}43.48 \\
(39.80)\end{array}$ \\
\hline
\end{tabular}

Figures in parentheses are arcsine transformed values.

In a column / row, means followed by a common letter are not significantly different at $1 \%$ level (LSD).

$\begin{array}{lccc} & \text { T } & \text { DAT } & \text { T } \times \text { DAT } \\ \text { Significance } & 0.01 & 0.01 & \text { NS } \\ \text { CD }(p=0.05) & 8.95 & 7.31 & 17.90\end{array}$

T- Treatment; DAT- Days after treatment

The bacterial symbionts in combination with $B t$ could produce good results in short period of time. EPNs would have taken some time to release the symbiont from its bacterial pouch. However, the symbionts along with $B t$ would have readily reached insect haemocoel in short period of time to produce good results. Between the two EPNs and their bacterial symbionts tested the native $S$. kushidai and its bacterial symbiont $X$. japonica yielded good results against rice leaffolder larva. This statement is further confirmed by getting lower values of $\mathrm{LC}_{50}$ and $\mathrm{LT}_{50}$ for $S$. kushidai in our earlier laboratory studies in the present research work.

\section{References}

Ahmed, H., Khan, R.B., Sharma. D., Jamwal V.V.S and Gupta, S. 2010. Seasonal incidence, infestation and trap catches of Cnaphalocrocis medinalis (Guenee) in rice. Annals Pl. Prot. Sci., 18(2):38-383.

Arthurs, S., Heinz, K.M and Prasifka, J.R. 2004. An analysis of using entomopathogenic nematodes against above-ground pests. Bull. Entomol. Res., 94: 297-306.

Bedding, R.A and Molyneux, A.S. 1982. Penetration of insect cuticle by infective juveniles of Heterorhabditis spp. (Heterorhabditidae: Nematoda). Nematologica., 28:354-359.

Dale, D. 1986. Insect pests of rice plant their biology and ecology. In: Rice Insects: biology ecology, Ed. Heinrichs E.A, Intl. Rice Res. Instt., Los Banos, Phillippines. Pp.363-485.

Divya, K and Sankar, M. 2009. Entomopathogenic nematodes in pest 
management. Indian J. Sci. Technol., 2(7): 53-60.

Han, G., Xu, J and Lu, Z. 2016. Genome of Cnaphalocrocis medinalis Granulosisvirus, the first Crambidae-infecting Betabaculovirus isolated from Rice leaffolder to sequenced. PLoS One., 11(2): e0147882.

Heinrichs, E.A., Medrano, F.G and Rapusas, H.R. 1985. Mass rearing of rice leaf folder. In: Genetic Evaluation for Insect Resistance in Rice. Intl. Rice Res. Instt., Los Banos, Phillipines. 35-40 pp.

Jung, S and Kim, Y. 2006. Synergistic effect of entomopathogenic bacteria (Xenorhabdus sp. and Photorhabdus temperata ssp. temperata) on the pathogenicity of Bacillus thuringiensis ssp. aizawai against Spodoptera exigua (Lepidoptera: Noctuidae). Environ. Entomol., 35(6): 1584-1589.

Kaya, H.K and Stock, S.P. 1997. Techniques in insect nematology. In L.A. Lacey (eds.), Manual of Techniques in Insect Pathology, Academic Press, London. pp. 281-324

Kumar, S.N., Amarnath, R., Madhavi, J., Prasanna, P.L., Kalyani, P and Rao, C.V. 2011. Estimation of endosulfan insecticide residues in paddy of Krishna district. Int. J. Pharm. Chem., 1(1): 55-56.

Manjunath, T.M. 1988. Procedures and techniques for mass production of the rice moth, Corcyra cephalonica. Proc. Sum. Instt. Tech. Mass. Prod. Biocontrol Agents Mgmt. Pests Dis. TNAU, Coimbatore, June 17-26.

Muthulakshmi, M., Kumar, S and Subramanian, S. 2011. Bilogy of entomopathogenic nematodes, Heterorhabditis spp and Steinernema spp. J. Biocicon., 4(1): 52.

Park, H.H., Park, C.G and Ahn, J.J. 2014. Oviposition model of Cnaphalocrocis medinalis (Lepidoptera: Pyralidae). J. of Asia. Pac. Entomol., 17(4): 781-786.

Rao, Y., Dong, G., Zeng, D., Hu, J., Zeng, L., Gao, Z., Zhang, G., Guo, L and Qian, Q. 2010. Genetic analysis of leaf folder resistance in rice. J. Genet. Genomics., 37: 325-331.

Sankarm, M., S.Prasad, J., Padmakumari, A.P., Katti, G and Divya, K. 2009. Combined application of two entomopathogenic nematodes,Heterorhabditis indica and Steinernema asiaticum to control therice leaf folder, Cnaphalocrocis medinalis (Guen.). J. Biopesticides., 2(2): 135-140.

Srinivas, P.R and Prasad, J.S. 1991. Record of DD 136 nematode infection on rice leaf folder (Cnaphalocrosis medinalis). Indian J. Agric Sci., 61:348-349.

Suganthi, R., Murugesan, N., Ayyanar, S and Pillai, M.A.K. 2011. Microbes; the invisible and invincible Gaurdians of our Livelihood and Food Security through Pest Management In; Proc. National conference on harnessing the power of microbes for Better food, Agro industry, Health and Environment. Coimbatore 2011, p.19.

Uma, G.P., Prabhuraj, A and Vimala. 2010. Bioefficacy of Photorhabdus luminescens, a symbiotic bacterium against Thrips palmi Karny (Thripidae: Thysanoptera) $J$. Biopesticides., 3(2): 458 - 462458.

White, G.F. 1927. A method for obtaining infective juveniles from cultures. Science, 66: 302-303.

Xiao MK, (1990). Preliminary study on relationship between leaf sheath rotted disease and rice leaf roller. Plant Protection. 16: 29-29.

\section{How to cite this article:}

Karthikeyan, S., T. Abdul Razak, A. Manivannan, S. Sekar and Muthu Kumar, P.K. 2017. Efficacy of Steinernema feltiae Filipjev, Native Entomopathogenic Nematode kushidai Mamiya and their Bacterial Symbionts against Cnaphalocrocis medinalis Guenee. Int.J.Curr.Microbiol.App.Sci. 6(5): 1839-1849. doi: https://doi.org/10.20546/ijcmas.2017.605.201 